\title{
Pertumbuhan Rumput Laut Gracilaria sp. Dengan Rasio N:P Yang Berbeda
}

\author{
Growth of Seaweed Gracilaria sp. With \\ Ratio N:P Different
}

\section{Vivian Ayu Cyntya, Gunawan Widi Santosa, Endang Supriyantini", dan Sri Yulina Wulandari}

\author{
Program Studi IImu Kelautan, Fakultas Perikanan dan IImu Kelautan, Universitas Diponegoro, \\ Jl. Prof. H. Soedarto, S. H, Tembalang, Semarang, Jawa Tengah 50275 Indonesia \\ *Email: supri_yantini@yahoo.com
}

\begin{abstract}
ABSTRAK
Rumput laut merupakan tumbuhan yang tidak dapat dibedakan antara akar, batang dan daun, sehingga seluruh bagian tubuhnya disebut dengan thallus. Rumput laut Gracilaria sp. merupakan salah satu sumber daya laut yang mudah dibudidayakan, mempunyai nilai ekomonis penting dan mempunyai prospek pasar yang cerah, baik di dalam negeri maupun luar negeri. Usaha budidaya rumput laut Gracilaria sp. perlu dilakukan guna meningkatkan produksinya. Rumput laut Gracilaria sp. memerlukan Nitrat dan Phosphat sebagai unsur hara makro yang digunakan untuk pertumbuhan. Penelitian ini bertujuan untuk mengetahui pengaruh penambahan rasio N:P yang berbeda terhadap laju pertumbuhan Gracilaria sp. Metode yang digunakan adalah metode eksperimental dengan Rancangan Acak Lengkap (RAL). Penelitian ini menggunakan 3 perlakuan dan 1 kontrol, yang masing-masing ada 3 ulangan. Media pemeliharaan menggunakan air laut yang ditambah zat N:P masing-masing dengan konsentrasi yang berbeda, yaitu : A (Kontrol), B (6:1), C (6:2), D (6:3). Hasil penelitian memperlihatkan bahwa berat rerata Gracilaria sp. selama 28 hari adalah sebagai berikut : A = 102,06 $\pm 0,04 \mathrm{~g} ; \mathrm{B}=103,41 \pm 0,57 \mathrm{~g}$; $C=106,53 \pm 0,66 \mathrm{~g}$ dan $\mathrm{D}=108,28 \pm 1,25 \mathrm{~g}$. Pertumbuhan mutlak Gracilaria sp. yang dihasilkan selama penelitian adalah sebagai berikut : $A=2,06 \pm 0,04 \mathrm{~g} ; \mathrm{B}=3,41 \pm 0,57 \mathrm{~g} ; \mathrm{C}=6,53 \pm 0,66 \mathrm{~g} ; \mathrm{D}=$ $8,28 \pm 1,25 \mathrm{~g}$. Laju pertumbuhan spesifik Gracilaria sp. yang dihasilkan selama penelitian, yaitu : A sebesar 0,07 $\pm 0,00 \%$ berat $(\mathrm{g})$ per hari; B sebesar 0,12 $\pm 0,02 \%$ berat $(\mathrm{g})$ per hari; C sebesar 0,23 \pm $0,02 \%$ berat $(\mathrm{g})$ per hari dan D sebesar 0,28 $\pm 0,04 \%$ berat $(\mathrm{g}$ ) per hari. Hasil penelitian menunjukkan bahwa penambahan N:P dengan rasio yang berbeda berpengaruh nyata terhadap pertumbuhan mutlak dan laju pertumbuhan spesifik Gracilaria sp. ( $p<0,01)$. Hasil penelitian disimpulkan bahwa semakin tinggi konsentrasi rasio N:P dapat meningkatkan total biomassa dan laju pertumbuhan spesifik.
\end{abstract}

Kata kunci : pertumbuhan, Gracilaria sp., rasio N:P, nitrat, phosphat

\begin{abstract}
Seaweed is a plant which can not be distinguished between true roots, stalks and leaves, therefore its entire body is called a thallus. Gracilaria $s p$. is a seaweed which is relatively easy to cultivate, has high economical value and bright marketing prospect either in domestic or foreign markets. The effort to cultivate Gracilaria $s p$. needs to be done in order to increase the production. Seaweed Gracilaria sp. needs Nitrate and Phosphate as important macronutrients for its growth. This research aims to discover the effect of adding different N:P ratio towards Gracilaria $s p$. growth rate. The method used in this research was an experimental method with Completely Randomized Design. This research used three treatments and one control, each with three repetitions. The cultivation media was seawater with the addition of different $N: P$ ratios, which were: $A$ (Control), $B(6: 1), C(6: 2)$ and $D(6: 3)$. The results showed that the average weight of Gracilaria sp. for 28 days were as follows: $A=102,06 \pm 0,04 \mathrm{~g} ; \mathrm{B}=103,41 \pm 0,57 \mathrm{~g}$; $C=106,53 \pm 0,66 \mathrm{~g}$ and $\mathrm{D}=108,28 \pm 1,25 \mathrm{~g}$. The absolute growth of Gracilaria sp. during this research were: $A=2,06 \pm 0,04 \mathrm{~g} ; B=3,41 \pm 0,57 \mathrm{~g} ; C=6,53 \pm 0,66 \mathrm{~g} ; \mathrm{D}=8,28 \pm 1,25 \mathrm{~g}$. The specific growth rate for Gracilaria sp. during this research were: $A=0,07 \pm 0,00 \%$ weight $(\mathrm{g})$ per day; $\mathrm{B}=0,12 \pm 0,02$ $\%$ weight $(\mathrm{g})$ per day; $C=0,23 \pm 0,02 \%$ weight $(\mathrm{g})$ per day and $\mathrm{D}=0,28 \pm 0,04 \%$ weight $(\mathrm{g})$ per day. The result of this research showed that the addition of different $\mathrm{N}: \mathrm{P}$ ratios caused a significant effect on the absolute growth and the spesific growth rate of Gracilaria sp. $(p<0,01)$. The result of the study concluded that the higher concentration ratio of N:P given the higher either total biomassa and specific growth rate achieved.
\end{abstract}

Keywords : growth, Gracilaria sp., N:P ratios, nitrate, phosphate 



\section{PENDAHULUAN}

Rumput laut merupakan tanaman tidak dapat dibedakan antara akar, batang dan daun, sehingga seluruh bagian tubuh rumput laut disebut dengan thallus. Rumput laut terdiri dari 3 divisi, yaitu Rhodophyta, Phaeophyta dan Chlorophyta yang ketiganya dibedakan oleh kandungan pigmen dan klorofil. Pengelompokan menurut warna ini didasarkan pada pigmen yang terkandung di dalamnya yaitu fikoeritrin dan fikosianin pada rumput laut merah, fukosantin pada rumput laut coklat dan klorofil b pada rumput laut hijau (Anggadiredja et al., 2006). Salah satu jenis rumput laut yang banyak ditemukan di perairan Indonesia adalah jenis Gracilaria sp. Rumput laut Gracilaria sp. merupakan jenis algae merah yang banyak mengandung gel dan memiliki kemampuan mengikat air yang cukup tinggi. Rumput laut Gracilaria sp. merupakan salah satu sumber daya laut yang mudah dibudidayakan, mempunyai nilai ekomonis penting dan mempunyai prospek pasar yang cerah, baik di dalam negeri maupun luar negeri (Hasan et al., 2015). Rumput laut Gracilaria sp. merupakan tumbuhan yang mempunyai toleransi terhadap perubahan kondisi lingkungan serta dapat tumbuh pada perairan yang tenang (Alamsjah et al., 2009).

Keberhasilan budidaya rumput laut tidak lepas dari beberapa faktor seperti lingkungan, kualitas bibit, metode yang digunakan, ketersediaan nutrien, dan kepadatan atau bobot awal dalam pemeliharaan. Budidaya rumput laut Gracilaria sp. dapat dilakukan di dalam ruangan (indoor). Metode budidaya indoor lebih menguntungkan, karena kualitas air lebih mudah dikontrol, bebas dari predator dan panen mudah dilakukan. Metode indoor menggunakan akuarium dan media air laut dengan penambahan pupuk sebagai unsur hara. Penyerapan unsur hara pada rumput laut akan menambah nutrien dan kandungan agar (Anggadiredja et al., 2006).

Salah satu faktor kimia yang berpengaruh dalam pertumbuhan rumput laut adalah unsur hara Nitrogen dan Posforus. Tumbuhan dalam air laut memerlukan $\mathrm{N}$ dan $\mathrm{P}$ sebagai unsur hara makro yang digunakan untuk pertumbuhan. Penggunaan unsur N:P dengan rasio yang tepat diharapkan dapat melengkapi unsur hara yang diperlukan, sehingga dapat diserap oleh rumput laut guna menunjang pertumbuhan (Setiaji et al., 2012). Unsur $\mathrm{N}$ merupakan unsur makro yang diserap tanaman untuk merangsang pertumbuhan dan digunakan untuk menyusun protein yang diperlukan dalam proses pembentukan RNA, DNA, klorofil, sitokrom dan untuk menghasilkan koenzim. Nitrogen diperlukan sebagai sumber energi dalam proses fotosintesis. Unsur $P$ merupakan penyusun ikatan pirophospat dari ATP (Adenosine Tri
Phosphat) yang kaya energi dan merupakan bahan bakar untuk semua kegiatan biokimia di dalam sel (Campbell et al., 1999).

Penelitian ini bertujuan untuk mengetahui pengaruh penambahan unsur $\mathrm{N}$ dan $\mathrm{P}$ yang berbeda terhadap pertumbuhan mutlak dan laju pertumbuhan spesifik Gracilaria sp.

\section{METODE PENELITIAN}

Materi yang digunakan pada penelitian ini adalah rumput laut Gracilaria sp. yang berasal dari budidaya rumput laut di Balai Besar Perikanan Budidaya Air Payau (BBPBAP), Jepara. Bibit rumput laut Gracilaria sp. dipilih yang masih segar dengan ciri tidak terdapat bercak putih, tidak terkelupas, segar, elastis, sehat, masih muda dan berumur 25-35 hari (Setiyaningsih, 2011). Rumput laut diaklimatisasi selama 7 hari agar dapat beradaptasi dengan lingkungan yang baru. Rumput laut yang digunakan pada masing-masing akuarium yaitu sebanyak $\pm 100 \mathrm{~g}$.

Wadah uji yang digunakan untuk penelitian ini adalah akuarium berbahan kaca dengan ukuran $25 \mathrm{~cm} \times 25 \mathrm{~cm} \times 25 \mathrm{~cm}$ sebanyak 12 buah. Wadah uji disesuaikan dengan jumlah rumput laut supaya dapat hidup secara normal (Yulianto et al., 2014). Media uji adalah media air laut dari BBPBAP Jepara yang telah difilter dengan salinitas $24 \%$. Kisaran salinitas yang layak untuk pertumbuhan rumput laut adalah 15\%o 30\% (Widiastuti, 2011). Media air laut yang telah difilter ditambah dengan unsur $\mathrm{N}$ dalam bentuk Nitrat yang bersumber dari $\mathrm{KNO}_{3}$ dan ditambahkan dengan unsur $P$ dalam bentuk Phospat yang bersumber dari TSP (TSP 46 ). Pembuatan larutan dilakukan dengan menggunakan metode pengenceran, dimana pembuatan larutan disesuaikan dengan rasio $\mathrm{N}$ :P yang akan dibuat untuk masing-masing perlakuan, dengan mennggunakan rumus pengenceran sebagai berikut :

$$
\mathrm{V}_{1} \times \mathrm{N}_{1}=\mathrm{V}_{2} \times \mathrm{N}_{2}
$$

Keterangan :

$\mathrm{V} 1$ = volume larutan stok (L)

$\mathrm{N} 1$ = konsentrasi larutan stok (ppm)

$\mathrm{V} 2$ = volume larutan setelah diencerkan (L)

$\mathrm{N} 2$ = konsentrasi larutan setelah diencerkan (ppm)

Metode penelitian yang digunakan adalah metode eksperimental laboratoris untuk menyelidiki hubungan sebab-akibat dengan cara menggunakan satu atau lebih kondisi perlakuan kemudian 
membandingkannya dengan satu atau lebih kelompok kontrol yang tidak dikenakan perlakuan (Budiyani et al., 2012). Rancangan percobaan yang dilakukan pada penelitian ini yaitu Rancangan Acak Lengkap (RAL). Pada penelitian ini diterapkan 3 perlakuan dan 1 kontrol pada tanaman uji, dimana masingmasing perlakuan dan kontrol diulang 3 kali. Penambahan larutan stok disesuaikan dengan konsentrasi rasio N:P yang akan diterapkan pada masing-masing perlakuan, yaitu : $A=$ Kontrol, $B=6: 1, C=6: 2, D=6: 3$. Sumber cahaya menggunakan lampu TL 40 watt $( \pm 2500$ lux $)$. Intensitas cahaya yang diperlukan untuk pertumbuhan Gracilaria sp. yaitu 1000-3000 lux. Pengaturan waktu pencahayaan (gelap dan terang) disesuaikan dengan kondisi di alam yaitu : 12 jam terang dan 12 jam gelap (Dawes, 1981). Pemeliharaan dilakukan selama 28 hari dan untuk menjaga kualitas air tiap 7 hari sekali dilakukan penggantian air sebanyak $100 \%$ dari akuarium.

Pengukuran parameter penelitian, berupa : pengukuran pertumbuhan rumput laut (berat) dilakukan setiap minggu sekali selama 28 hari masa penelitian, pengukuran kualitas air media penelitian (suhu, salinitas, $\mathrm{pH})$ selama 28 hari masa penelitian, pengukuran kadar nitrat dan phospat dalam air dilakukan setiap minggu sekali selama 28 hari masa penelitian dan pengukuran kadar nitrat dan phospat dalam rumput laut Gracilaria sp. dilakukan sebelum penelitian dan setelah selesai penelitian. Pengukuran pertumbuhan Gracilaria sp. dilakukan dengan menggunakan rumus berat mutlak dan SGR. Menurut Alamsjah et al. (2009), perhitungan berat mutlak dengan rumus sebagai berikut :

$$
w=W t-W_{0}
$$

Keterangan :

$\mathrm{W}=$ Pertambahan bobot rumput laut $(\mathrm{g})$

$\mathrm{Wt}=$ Berat akhir rumput laut $(\mathrm{g})$

Wo $=$ Berat awal rumput laut $(\mathrm{g})$

Menurut Alamsjah et al. (2009), Specific Growth Rate (SGR) dapat dihitung menggunakan rumus :

$$
S G R=((\operatorname{Ln} W t-\operatorname{Ln} W o) / t) \times 100 \%
$$

$$
\begin{aligned}
& \text { Keterangan : } \\
& \text { SGR = Laju pertumbuhan spesifik }(\% \\
& \text { perhari) } \\
& \begin{aligned}
\mathrm{Wt}= & \text { Berat akhir rumput laut }(\mathrm{g}) \\
\mathrm{Wo} & =\text { Berat awal rumput laut }(\mathrm{g}) \\
\mathrm{T} & =\text { Waktu (hari) }
\end{aligned}
\end{aligned}
$$

Hasil pengamatan, terutama pertumbuhan Gracilaria sp. dianalisis dengan menggunakan analisis varian untuk mengetahui besarnya pengaruh penambahan $\mathrm{N}: \mathrm{P}$ dengan rasio yang berbeda terhadap pertumbuhan rumput laut Gracilaria sp. Analisis data dilakukan dengan menggunakan uji ANOVA, uji korelasi dan regresi linier seserhana.

\section{HASIL DAN PEMBAHASAN}

Hasil penelitian memperlihatkan bahwa pertumbuhan Gracilaria sp. selama 28 hari mengalami peningkatan berat basah setiap minggunya (Tabel 1). Hasil pencapaian rerata berat rumput laut selama 28 hari, pada perlakuan A (kontrol), B (6:1), C (6:2) dan D (6:3) adalah sebagai berikut : $102,06 \mathrm{~g}$; $103,41 \mathrm{~g} ; 106,53 \mathrm{~g} ; 108,28 \mathrm{~g}$. Pertambahan berat terbaik dicapai oleh perlakuan $D$ dengan rasio $N: P$ 6:3. Hal ini diduga pada rasio $\mathrm{N}: \mathrm{P}$ tersebut unsur $\mathrm{N}$ dan $\mathrm{P}$ yang dibutuhkan rumput laut untuk pertumbuhan telah tercukupi. Sedangkan hasil penelitian Kushartono et al. (2009), pertumbuhan Gracilaria sp. tertinggi dicapai pada pemberian unsur N:P:K dengan perbandingan $6: 2: 1$. Perbedaan pertumbuhan Gracilaria ini diduga adanya unsur $P$ yang mempengaruhi. Menurut Round (1977), unsur $P$ merupakan bagian dari inti sel dan penting untuk pembelahan sel. Kekurangan unsur $P$ dapat menyebabkan pertumbuhan kerdil, jumlah tunas sedikit, dan lambatnya pertumbuhan. Menurut Lapointe (1987), unsur $P$ berperan sebagai faktor pembatas dalam proses fotosintesis. Pertambahan berat terendah Gracilaria sp. terjadi pada perlakuan A (kontrol). Hal ini diduga karena nutrien pada perlakuan A (kontrol) hanya bersumber dari media air laut murni dan tidak ada penambahan unsur $\mathrm{N}$ dan $\mathrm{P}$. Sehingga secara tidak langsung akan berpengaruh terhadap pertumbuhan rumput laut. Hasil pertumbuhan rumput laut Gracilaria sp. juga diperkuat dengan hasil pertumbuhan mutlak pada tiap perlakuan. Pertumbuhan mutlak Gracilaria sp. selama 28 hari memperlihatkan pertumbuhan mutlak Gracilaria sp. pada perlakuan $A=2,06 \mathrm{~g}$, perlakuan $B=3,41 \mathrm{~g}$, perlakuan $C=6,53 \mathrm{~g}$ dan perlakuan $\mathrm{D}=$ $8,28 \mathrm{~g}$ (Gambar 1). Hasil uji varian data parameter pertumbuhan mutlak Gracilaria sp. sebagai respon dari masing-masing perlakuan, memperlihatkan nilai sig : 0,000 , nilai $p<0,01$ sehingga disimpulkan bahwa, terdapat perbedaan sangat nyata. Hal ini karena perbedaan konsentrasi rasio $\mathrm{N}$ : $\mathrm{P}$ yang 
ditambahkan pada masing-masing perlakuan. Laju pertumbuhan spesifik (SGR) Gracilaria sp. selama 28 hari memperlihatkan SGR Gracilaria sp. pada perlakuan $A=0,07 \%$ berat (g) per hari, perlakuan $\mathrm{B}=0,12 \%$ berat (g) per hari, perlakuan $C=0,23 \%$ berat (g) per hari dan perlakuan $\mathrm{D}=0,28 \%$ berat (g) per hari (Gambar 2).

Pertambahan nilai berat ini juga dapat dilihat dari nilai SGR yang semakin meningkat dari minggu ke-1 hingga minggu ke-4 yang berkisar antara 0,07-0,28\% berat (g) per hari. Hasil uji varian data parameter SGR Gracilaria sp. sebagai respon dari masing-masing perlakuan, memperlihatkan nilai sig : 0,000, nilai $p<0,01$ sehingga disimpulkan bahwa, terdapat perbedaan sangat nyata. Adanya kenaikan pertumbuhan menunjukkan bahwa perkembangan rumput laut sudah memasuki tahap perpanjangan sel, karena tersedianya unsur hara yang cukup untuk pertumbuhan (Hendrajat, 2008). Rumput laut melakukan proses difusi melalui seluruh bagian tubuhnya dalam proses penyerapan nutrien. Membran sel adalah bagian terluar dari rumput laut setelah dinding sel, membran sel memiliki fungsi sebagai pelindung isi sel yang terdapat dalam tubuh dan akan mengatur nutrien yang keluar dan masuk ke dalam sel. Sifat membran sel yang semi permiable akan menyeleksi unsur hara yang masuk ke dalam sel tanaman. Banyaknya nutrien yang terdifusi ke dalam sel tergantung oleh kadar

Tabel 1. Berat basah Gracilaria sp. (g) pada rasio N:P yang berbeda selama 28 Hari masa tanam ( $\bar{x} \pm \mathrm{SD}, \mathrm{n}=3)$

\begin{tabular}{cccccc}
\hline \multirow{2}{*}{ Perlakuan } & \multicolumn{5}{c}{ Minggu ke } \\
\cline { 2 - 6 } & 0 & 1 & 2 & 3 & 4 \\
\hline A & $100,00 \pm 0,00$ & $100,08 \pm 0,02$ & $101,12 \pm 0,04$ & $101,41 \pm 0,44$ & $102,06 \pm 0,04$ \\
B & $100,00 \pm 0,00$ & $101,38 \pm 0,19$ & $101,91 \pm 0,06$ & $102,33 \pm 0,21$ & $103,41 \pm 0,57$ \\
C & $100,00 \pm 0,00$ & $102,77 \pm 0,03$ & $103,89 \pm 0,04$ & $105,60 \pm 0,41$ & $106,53 \pm 0,66$ \\
D & $100,00 \pm 0,00$ & $103,74 \pm 0,86$ & $105,13 \pm 0,59$ & $106,43 \pm 0,47$ & $108,28 \pm 1,25$ \\
\hline
\end{tabular}

Keterangan : $A=$ Kontrol; $B=6: 1 ; C=6: 2 ; D=6: 3$

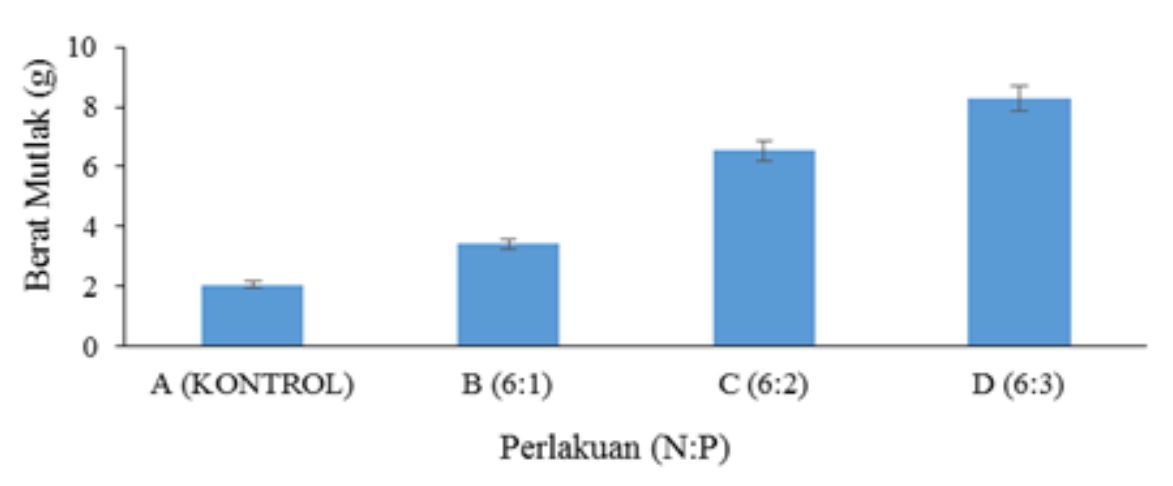

Gambar 1. Histogram pertumbuhan mutlak Gracilaria sp. dengan rasio N:P yang berbeda selama 28 hari masa tanam

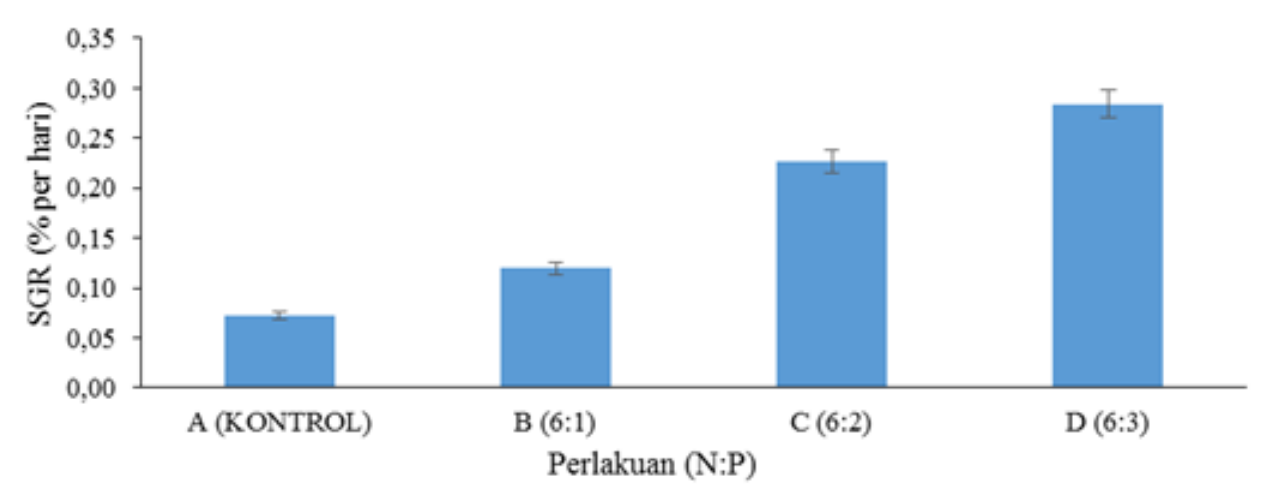

Gambar 2. Histogram laju pertumbuhan spesifik Gracilaria sp. dengan rasio N:P yang berbeda selama 28 hari masa tanam 
nutrien yang ada di dalam maupun di luar sel. Nutrien di luar sel yang kadarnya lebih tinggi dibandingkan di dalam sel dapat menyebabkan nutrien yang berada dari luar sel akan berdifusi bebas ke dalam sel sesuai kebutuhannya. Nutrien bermanfaat untuk meningkatkan aktivitas metabolisme sel dengan cara masuk ke dalam sel sedikit demi sedikit, lalu akan mengembangkan vakuola yang terdapat di dalam sel. Vakuola memiliki fungsi dalam kehidupan karena mekanisme pertahanan hidup tumbuhan tergantung pada kemampuan vakuola menjaga konsentrasi zat-zat terlarut di dalamnya. Volume vakuola akan bertambah karena masuknya nutrien ke dalam sel dan akan menyebabkan berat rumput laut akan meningkat (Loban et al., 1997).

Laju pertumbuhan rumput laut yang dianggap menguntungkan adalah diatas 3$5 \%$ pertambahan berat per hari (Aslan, 1998). Hasil SGR dari perlakuan A (kontrol), B (6:1), C (6:2) dan D (6:3) belum termasuk dalam kategori laju pertumbuhan yang menguntungkan. Rendahnya laju pertumbuhan rumput laut diduga juga diakibatkan karena pergantian media yang dilakukan 7 hari sekali, sehingga tanaman belum melakukan penyerapan nutrien pada media uji secara optimal. Kendala ini juga dialami saat pemupukan di tambak adalah seringnya pergantian air, sehingga mengurangi efektifitas pupuk, menyebabkan tanaman menjadi terhambat pertumbuhannya, bahkan bisa mengalami kematian (Dinas Kelautan dan Perikanan, 2009). Faktor lain diduga karena adanya tekanan osmotik yang tidak seimbang, maka pertukaran air, nutrien dan ion-ion yang dibutuhkan oleh sel menjadi tidak optimal. Pada konsentrasi nutrien yang tepat tekanan osmotik di dalam sel tidak akan berubah dengan cepat, sehingga pertukaran air dan zat hara berjalan lancar dan proses metabolisme yang baik dapat menghasilkan pertumbuhan yang optimal (Lobban et al., 1997).

Konsentrasi Nitrat pada awal penelitian adalah A sebesar 3,23 mg/L, B sebesar 6,46 mg/L, C sebesar 9,69 mg/L, D sebesar 12,92 mg/L. Sedangkan Konsentrasi Phospat pada awal penelitian adalah $A$ sebesar 0,01 mg/L, B sebesar 0,55 mg/L, C sebesar 1,09 mg/L, D sebesar 1,63 mg/L. Konsentrasi nitrat dan phospat di media mengalami kenaikan dan penurunan pada setiap minggunya selama 28 hari masa pemeliharaan. Kenaikan konsentrasi nitrat dan phospat pada media pemeliharaan terjadi karena adanya proses pengembalian kembali senyawa N, P dari rumput laut ke air karena proses metabolisme rumput laut yang tidak mampu mentolerir keberadaan unsur $\mathrm{N}, \mathrm{P}$ pada thallus. Sedangkan adanya penurunan kandungan nitrat dan phospat pada air terjadi karena adanya unsur $N$, $P$ yang mampu diserap baik oleh rumput laut sesuai kebutuhannya melalui proses difusi karena perbedaan konsentrasi antara thallus rumput laut dan N, P yang ada pada media tanam kemudian masuk ke dalam jaringan. Jumlah nitrat yang naik turun di setiap minggunya disebabkan karena sifat nitrat yang tidak stabil (Nugroho et al., 2014). Kenaikan konsentrasi nitrat, phospat di dalam media pemeliharaan diduga karena proses pengadukan (mixing) media menggunakan aerator dapat meninggalkan endapan senyawa di bawah permukaan akuarium. Penambahan konsentrasi nitrat dan phospat pada semua perlakuan dapat menyebabkan pertumbuhan rumput laut tidak optimal, hal ini terlihat pada ujung thallus menjadi putih bening dan lunak. Ketika konsentrasi nitrogen terlalu tinggi dan mencapai kapasitas maksimum dapat menyebabkan histosit pada thallus yaitu rangkaian reaksi fisiologis dan biokimia yang akan membatasi perkembangan kandungan warna dan juga akan menghambat pertumbuhan dimana kloroplas dalam thallus rumput laut Gracilaria sp. menjadi rusak dengan ciri-ciri jumlah tilakoid meningkat dan thallus menjadi lunak, lama kelamaan percabangan menjadi tidak menentu hingga akhirnya melarut dalam air, volume kloroplas meningkat dan butiran starch grains di dalam kloroplas berakumulasi secara signifkan. Pernyataan tersebut sesuai dengan hasil penelitian yang menunjukkan bahwa pada ujung thallus rumput laut semua perlakuan mengalami perubahan warna menjadi putih bening di akhir penelitian (Gambar 3). Tekstur pada ujung thallus rumput laut semua perlakuan mengalami perubahan menjadi lunak di akhir penelitian (Gambar 3). Rumput laut yang telah hancur akan mati dan mengotori perairan dan diduga mengalami dekomposisi yang menyebabkan konsentrasi nitrat menjadi tinggi. Salah satu faktor yang menyebabkan konsentrasi nitrat tinggi pada perairan diakibatkan oleh perombakan dari proses dekomposisi rumput laut yang telah mati (Anggorowati, 2004).

Kisaran konsentrasi kandungan N dalam bentuk nitrat yang optimal untuk pertumbuhan laut antara 0,9-3,5 mg/L (Hutagalung dan Rozak, 1997). Pendapat ini tidak sesuai dengan penelitian yang 

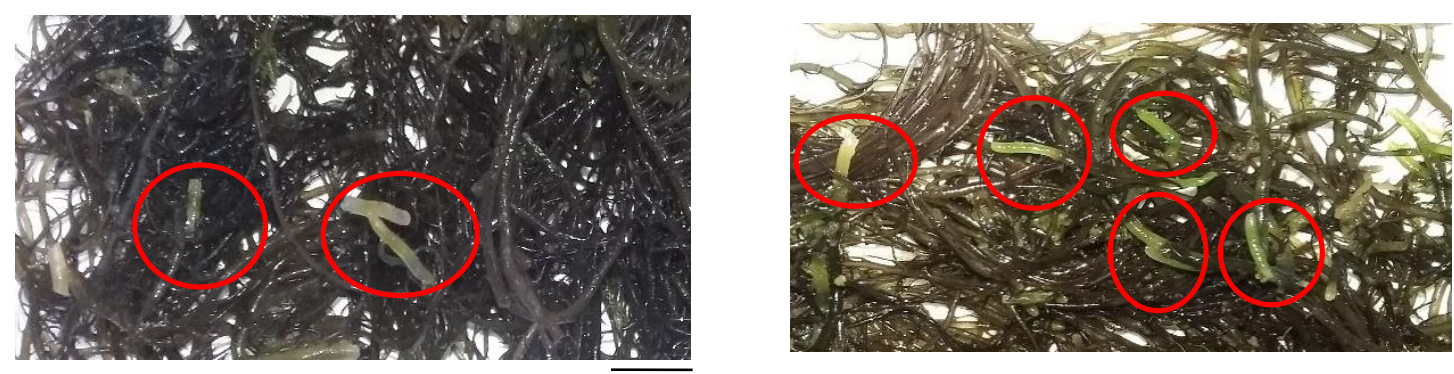

Gambar 3. Kondisi rumput laut Gracilaria sp. yang mengalami perubahan tekstur dan warna pada Ujung Thallus (Skala Bar $=10 \mathrm{~mm}$ )

Tabel 2. Kandungan Penyerapan Nitrat (mg/L) pada Rumput Laut Gracilaria sp. pada Hari ke0 dan ke-28 ( $\bar{x} \pm \mathrm{SD}, \mathrm{n}=3)$

\begin{tabular}{ccccc}
\hline Waktu & \multicolumn{4}{c}{ Perlakuan } \\
\cline { 2 - 5 } & A & B & C & D \\
\hline T0 & $0,00 \pm 0,00$ & $0,00 \pm 0,00$ & $0,00 \pm 0,00$ & $0,00 \pm 0,00$ \\
T28 & $0,02 \pm 0,03$ & $0,01 \pm 0,02$ & $0,37 \pm 0,54$ & $0,07 \pm 0,06$ \\
\hline
\end{tabular}

Tabel 3. Kandungan Penyerapan Phospat (mg/L) pada Rumput Laut Gracilaria sp. pada Hari ke-0 dan ke-28 ( $x \pm S D, n=3)$

\begin{tabular}{ccccc}
\hline Waktu & \multicolumn{4}{c}{ Perlakuan } \\
\cline { 2 - 5 } & A & B & C & D \\
\hline T0 & $0,05 \pm 0,00$ & $0,05 \pm 0,00$ & $0,05 \pm 0,00$ & $0,05 \pm 0,00$ \\
T28 & $0,07 \pm 0,11$ & $0,15 \pm 0,10$ & $0,14 \pm 0,23$ & $0,34 \pm 0,20$ \\
\hline
\end{tabular}

dilakukan bahwa kisaran nitrat yang diserap oleh rumput laut Gracilaria sp. selama panen berkisar sekitar 0,01-0,37 mg/L (Tabel 2), kisaran tersebut menunjukkan bahwa nitrat yang diserap oleh rumput laut belum optimal untuk pertumbuhan. Unsur $\mathrm{N}$ memiliki peran sebagai penyusun atau bahan dasar protein dan pembentukan klorofil. Komponen utama penyusun klorofil adalah $\mathrm{N}$ dan $\mathrm{Mg}$. Kekurangan $\mathrm{N}$ dalam bentuk nitrat dapat menyebabkan depigmentasi pada thallus rumput laut (Dawes, 1981). Pernyataan tersebut sesuai dengan hasil penelitian yang menunjukkan bahwa pada ujung thallus rumput laut semua perlakuan mengalami perubahan warna menjadi putih bening di akhir penelitian. Keterbatasan nitrogen dalam perairan menyebabkan penurunan kandungan klorofil dalam rumput laut dan dapat menyebabkan pertumbuhannya berhenti (Ribeiro et al., 2013). Tumbuhan yang mengalami kekurangan nitrat dapat mengakibatkan proses fotosintesis di dalam tubuhnya tidak dapat berjalan optimal, karena diduga proses pembentukan klorofilnya tidak sempurna, sedangkan klorofil berfungsi sebagai penangkap cahaya dan berperan penting dalam fotosintesis ( $\mathrm{Yu}$ dan Yang, 2008). Kisaran phospat yang optimun untuk pertumbuhan rumput laut adalah 0,051-1,00 mg/L (Khasanah, 2013). Pendapat ini sesuai dengan penelitian yang dilakukan bahwa kisaran phospat yang diserap oleh rumput laut Gracilaria sp. selama penelitian sekitar 0,07-0,34 $\mathrm{mg} / \mathrm{L}$ (Tabel 3).

Kualitas media pemeliharaan yang diukur selama penelitian menunjukkan rerata kisaran salinitas 22-25\%o, menurut Widiastuti (2011) salinitas optimum berkisar antara $15-30 \%$. Kisaran tersebut termasuk dalam kisaran optimal, sehingga kisaran salinitas pada media yang terukur diduga masih dapat mendukung pertumbuhan Gracilaria sp. Derajat keasaman $(\mathrm{pH})$ media pemeliharaan berkisar antara 7-9, sedangkan menurut Widiastuti (2011) pH optimun berkisar antara 6-9, sehingga kisaran tersebut termasuk dalam kisaran yang optimal. Lobban et al. (1997) menyatakan bahwa setiap enzim di dalam sel mempunyai nilai $\mathrm{pH}$ optimum yang berlainan, sehingga pada kisaran $\mathrm{pH}$ yang tepat enzim akan bekerja secara optimal. Sehingga kisaran $\mathrm{pH}$ pada media pemeliharaan masih dapat mendukung pertumbuhan Gracilaria sp. 
Kisaran suhu pada media pemeliharaan berkisar antara $23-28^{\circ} \mathrm{C}$, sedangkan menurut Poncomulyo et al. (2006) suhu optimun berkisar antara $20-28^{\circ} \mathrm{C}$, sehingga kisaran suhu yang terukur masih termasuk dalam kisaran yang optimal walaupun setiap hari mengalami perubahan.

\section{KESIMPULAN}

Perlakuan rasio N:P yang berbeda dapat meningkatkan pertumbuhan rumput laut Gracilaria sp. Rasio N:P (6:3) menghasilkan pertumbuhan rumput laut Gracilaria sp. yang tertinggi dengan nilai pertumbuhan mutlak $8,28 \mathrm{~g}$ dan laju pertumbuhan spesifik (SGR) $0,28 \%$ berat (gram) per hari.

\section{REFERENSI}

Alamsjah, M.A., Tjahjaningsih, W. \& Pratiwi, A. 2009. Pengaruh Kombinasi Pupuk NPK Dan TSP Terhadap Pertumbuhan, Kadar Air Dan Klorofil A Gracilaria verrucosa. J. IImiah Perikan. Kel. 1(1):103-116.

Anggadiredja, J.T., A. Zatnika, H. Purwoto dan S. Istini. 2006. Rumput Laut : Pembudidayaan, Pengolahan dan Pemasaran Komoditas Perikanan Potensial. Penebar Swadaya, Jakarta, 40-47 hlm.

Anggorowati, D.A. 2004. Bioeliminasi Nitrat oleh Gracilaria salicornia pada Kegiatan Marikultur. UPT Loka Pengembangan Bio-Industri Mataram-Puslit Oseanografi, 297-203 hlm.

Aslan, L.M. 1998. Budidaya Rumput Laut. Kanisius, Yogyakarta. $37 \mathrm{hlm}$

Budiyani, F.B., Suwartimah, K. \& Sunaryo. 2012. Pengaruh Penambahan Nitrogen Dengan Konsentrasi yang Berbeda terhadap Laju Pertumbuhan Rumput Laut Caulerpa racemosa var. Uvifera. J. Mar. Res., 1(1): 10-18.

Campbell, N.A., Reece, J.B. \& Mitchell, L.G. 1999. Biology. University of Virginia, $1280 \mathrm{p}$.

Dawes, C.J., 1981. Marine Botany. John Wiley Dawson University of South Florida, New York, 480 p.

Dinas Kelautan dan Perikanan. 2009. Teknik Budidaya Rumput Laut Gracilaria sp. dan Eucheuma sp. Direktorat Jenderal Perikanan Budidaya, Sulawesi Tengah, $55 \mathrm{hlm}$.

Hasan, M., Rejeki, S. \& Wisnu, R. 2015. Pengaruh Bobot Awal Yang Berbeda Terhadap Pertumbuhan Gracilaria sp. yang dibudidayakan dengan Metode Longline di Perairan Tambak Terabrasi Desa Kaliwlingi Kabupaten Brebes. J. Aqua. Manag. Technol. 4(2):92-99.

Hendrajat, E.A. 2008. Pertumbuhan Rumput Laut Gracilaria verrucosa pada Dosis Saponin yang Berbeda dalam Bak Terkontrol. Dalam: Prosiding Seminar Nasional Kelautan IV Tanggal 24 April 2008. Surabaya, pp. 4-8.

Hutagalung, H.P. \& Rozak, A. 1997. Metode Analisis Air Laut, Sedimen dan Biota Laut. Institut Pertanian Bogor, Bogor. $182 \mathrm{hlm}$.

Khasanah, U. 2013. Analisis Kesesuaian Perairan Untuk Lokasi Budidaya Rumput Laut Eucheuma cottonii di Perairan Kecamatan Sajoanging Kabupaten Wajo. [Skripsi]. Program Sarjana, Universitas Hasanuddin, Makassar, 75 hlm.

Kushartono, Edi, W., Suryono \& Endah, S. 2009. Aplikasi Perbedaan Komposisi N, $\mathrm{P}$ dan $\mathrm{K}$ pada Budidaya Eucheuma cottonii di Perairan Teluk Awur, Jepara. Ilmu Kelautan: Ind. J. Mar. Sci. 14(3): 164-169.

Lapointe, B.E. 1987. Phosporus and Nitrogen Limited Photosintesis and Growth of Gracilaria ticvahiae (Rhodophyceae) in the Florida Keys: An Experimental Field Study. Mar. Biol. 93(4):561-568

Lobban, C.S., Harrison, P.J., Hurd, C.L. \& Bischof, K. 1997. Seaweed Ecology and Physiology. Cambridge University Press, United States of America, 13-71 pp.

Nugroho, A.S., Tanjung, S.D. \& Hendrarto, B. 2014. Distribusi Serta Kandungan Nitrat dan Phospat di Perairan Danau Rawa Pening. Jurnal Bioma. 3(1):27-41.

Poncomulyo, T., H. Maryani, dan L. Kristiani. 2006. Budidaya dan Pengolahan Rumput Laut Agro Media Pustaka, Jakarta. $68 \mathrm{hlm}$.

Ribeiro A., Tesima, K.E., Tesima, J.M.C. \& Yokoya, N.S. 2013. Effects of Nitrogen and Phosphorus Availabilities on Growth, Pigment, and Protein Contents in Hypnea cervicornis J. Agardh (Gigartinales, Rhodophyta). J. App. Phycol., 25:1151-1157.

Round. F.E. 1977. The Biology of The Algae. Edward Arnold Publisher. London. Pp 147-161.

Setiaji, K., G.W. Santosa dan Sunaryo. 2012. Pengaruh Penambahan NPK dan Urea pada Media Air Pemeliharaan terhadap Pertumbuhan Rumput Laut Caulerpa 
racemosa var. uvifera. J. Mar. Res. $1(2): 45-50$.

Setiyaningsih, Heryati. 2011. Kelayakan Usaha Budidaya Rumput Laut Kappaphycus alvarezii dengan Metode Longline dan Strategi Pengembangannya di Perairan Karimunjawa. [Tesis]. Sekolah Pascasarjana, Institut Pertanian Bogor, Bogor, $74 \mathrm{hlm}$.

Widiastuti, I.M. 2011. Produksi Gracilaria verrucosa yang Dibudidayakan di Tambak dengan Berat Bibit dan Jarak
Tanam yang Berbeda. J. Agrisains. 12(1):57-62.

Yu, J., \& Yang, F. 2008. Physiological dan Biochemical Responses of Seaweed Gracilaria lemaneiformis to Concentration Changes $\mathrm{N}$ and $\mathrm{P}$. Exp. Mar. Biol. Ecol., 367:142-148.

Yulianto, B., Ario, R. \& Triono, A. 2014. Daya Serap Rumput Laut (Gracilaria sp.) Terhadap Logam Berat Tembaga (Cu) Sebagai Biofilter. IImu Kelautan: Ind. J. Mar. Sci. 2(2):72-78. 